\title{
Why auto-ethnography, solo service-user voice and reflective case study analysis are useful strategies for researching family-centred social work practice
}

\section{Anita Gibbs}

Anita moved to Dunedin in 1999 from the UK where she had been a probation officer. Since then she has researched, taught and published extensively in areas as varying as home detention, social work research methods, community treatment orders and more recently inter-country adoption, adoption and parenting. Anita is a registered social worker and adoptive parent.

\section{Abstract}

Family-centred social work practitioners often reflect upon and talk about their everyday work with families, but they rarely write about it, other than in case notes or for formal reports. If social work practitioners were to adopt a range of easy-to-use research strategies that focus on either one service-user, or one family case, or one practitioner experience, then they may be empowered to write and publish more about their work. This may then lead to a series of practitioner pieces aimed at improving knowledge and methods in family-centred social work practice. This article explores three 'One Voice strategies': those of auto-ethnography, solo service-user voice and reflective case study analysis, and their usefulness to researching family-centred social work practice. It argues that using such strategies are valid in everyday social work and that practitioners can make a difference to our knowledge of effectiveness in practice by telling us about just one story - the power of one!

\section{Introduction}

Practitioners are not familiar with researching and writing about their work for publication (McKenzie, 2008). They are usually immersed knee-deep in the everyday bustle of seeing and working with families, writing up case notes, ensuring that administration is complete and meeting with colleagues. Rarely do they have time for reading or writing (Orme and Powell 2007; Osmond and O'Connor 2006). Hopefully, they have time for reflection and analysis, and good supervision will assist the activity of reflection for improvement as a practitioner, and for improving the service to clients. It is not an expectation of agencies that practitioners undertake research, nor publication of their understanding of effectiveness in family-centred social work, even though on an everyday basis thousands of social workers in New Zealand are, in effect, gathering data, as they work with families, about whether or what they are doing is making a difference (Munford and Sanders 2003). I would like to read about what practitioners are doing, more often than I do in the academic and practitioner journals and it is my contention that apart from time, practitioners need some useful frameworks to begin to organise what they do and how they might present an analysis of it to readers of journals such as this one. This piece therefore focuses on exploring the usefulness of what I term 'One Voice strategies'; that is, a range of strategies focusing upon gathering the real stories and experiences of just one individual or case, in order to reflect upon and present the key 
practice or policy messages to enhance effectiveness and understanding in family-centred practice. One Voice strategies do not necessarily have to be viewed as research, but for the sake of argument I do view them as valid research (see later section), so that practitioners can apply them systematically to the work with families that they are doing, and reflectively write about the lessons they have learned from family-centred practice.

In the following sections I present an overview of One Voice strategies, outline what each strategy is, with examples, and consider some key issues in using the strategies. I will explore what the strengths and weaknesses of the strategies are and apply them to researching family-centred social work practice. It is hoped that this piece will encourage family-centred social work practitioners to provide written accounts of the activity and impact of their practice with families and individuals, and their own lived experiences of 'normal' daily social work practice (Craig 2007). We do not only need large social work research projects to learn about social work, useful as they are (Gibbs 2012), but we also need more honest and frank assessments by people at the coal face, to complement what we can learn from large-scale research.

\section{One Voice strategies}

At its simplest, one truth is still one truth, even if it is relative to all the other truths! Hence, a One Voice strategy is about acknowledging the experiences of one person, one family or one practitioner. The voice of just one person counts and is valid, even if others disagree with it (Swenson 2012). Of course, there are limits, as I am not saying anyone would want to write a story about a client who was racist or violent, or write a story where they themselves expressed discriminatory language - these would not be acceptable (though some publishers have done so), and this journal's aims are clearly about anti-discrimination. Yet, simply to tell a narrative, a family's lived experience, its high and lows, to tell it 'native' as Geertz in Donmoyer (2012) would say, is valid and important and we can learn from such narratives. It is the authentic voice, and it doesn't have to be deconstructed, or reconstructed, or spoken by another on behalf of another! This is where it may not be considered research, as so often the business of the researcher is to deconstruct and reconstruct, and sometimes the genuine voice of the participant is lost in this process. Lewis (2011) argues comprehensively that telling a story of real lived experience gives 'voice to the voiceless', so that by writing about one experience we are empowering the voiceless to speak. There are numerous examples of where a One Voice strategy has been used and reported on in the literature (Atkinson 2013; Craig 2007; Court and Abbas 2013; Davis 2006; Gibbs 2011; Mason 2013; Swain 2013; Swenson 2012).

Other reasons why One Voice strategies are useful include the opportunity to use a narrative to develop themes and highlight questions for a more extensive study or project with a group of service users; and to highlight themes from a particular kind of intervention more generally that will then influence the development of policy and practice at the grass roots or local levels. A One Voice strategy might be useful in advocacy generally (Craig 2007) - narrating something you know about from personal experience in order to improve the quality of life for either your own family or for other families in similar situations. This is one aim of social work practice and by writing up your reflections of practice experiences you might advocate for understanding by other practitioners in similar situations. Using 
One Voice strategies for increased understanding of family-centred social work inevitably brings some challenges and these will be considered in the next sections alongside the nature and usefulness of the strategies themselves.

\section{Auto-ethnography}

The use of auto-ethnography as a strategy and process is about recounting and critically reflecting upon one's own lived experiences. According to Donmoyer (2012), it is about reflecting on personal experiences, and it differs from personal narrative, autobiography and life writing in general by being more critical and political (Speedy 2013). Auto-ethnography is about retelling a story, 'to challenge the underpinning assumptions of that story' (Gibbs 2011: 269). In my own case I used it to promote social justice and children's welfare (see below). Denzin (2006) calls auto-ethnography a '...methodology of the heart'. It also has transformative potential (Ellis and Bochner, 2006), and therefore it can make a difference - some would argue either for good or for ill. Auto-ethnography has been used to reflect on abuse, childhood experiences and violence, which has been therapeutic for the authors but often controversial in exposing others around them in a negative light (Tolich, 2010).

Ellis (2013: 43) tells us that '...writing auto-ethnography about recent and particular events...offers the possibility of continuous, ongoing life review'. This thereby gives social work practitioners a chance to write about events over time and to revisit them as they change their attitudes towards particular events as these events come to mean different things at different times to them. Also, auto-ethnography offers the chance, ' ...to rewrite, retell, and reanalyse these events in light of the responses we get to our published stories and the new experiences we have, much as we do in real life' (Ellis 2013: 44). Examples of auto-ethnography in social work practice include Jensen-Hart \& Williams (2010) who use auto-ethnography to frame critical reflection and apply it to social work knowledge, and Dumbleton (2013) who undertakes an auto-ethnographic reflection on the tensions between service providers and the families of those who care for children with learning disabilities. Dumbleton's piece in particular reviews her life as a parent, social worker and researcher over the course of 30 years, thus offering a detailed reflection of both recent and past events. Another example is from Wall $(2008 ; 2011)$ who explores the political and moral ethics of intercountry adoption as she reflects on her experience of adopting a child from Eastern Europe.

Finally, auto-ethnography offers a conversational element; it is not about presenting a series of facts, but rather a series of reflections in conversation with the audience to whom we are presenting. Writers of auto-ethnography are expecting feedback and hoping that what they write has an impact - for the social work auto-ethnographer the hope is for positive change.

The most controversial aspect of auto-ethnography is that the storyteller has control and potentially can expose vulnerable people to the limelight. When writing about aspects of one's practice the auto-ethnographer will need to take precautions to maintain the anonymity of others involved in the story. Hence, the auto-ethnographer might give themselves a nom de plume, and use pseudonyms to ensure others are not exposed (Morse 2002). Those who write auto-ethnography may also wish to let those mentioned in the story check and comment on their work. This can avoid embarrassing feedback later. Tolich (2010) has listed 10 ethical guidelines to undertaking auto-ethnography and practitioners undertaking this style of reflective storytelling would do well to follow these. 
Auto-ethnography as a qualitative research strategy has two strands - analytic auto-ethnography which may tell a personal story but then subject it to content analysis, or evocative auto-ethnography, which builds the analysis into the story (Jensen-Hart and Williams 2010). Both these strands could be used by social work practitioners to reflect on their practices. Using evocative or artistic auto-ethnography may well blur the boundaries of research and practice (Jensen-Hart and Williams 2010) but this could be in strength as it also attempts to build a bridge between practice and research where a narrative can make a difference to research and practice, and initiate further investigation.

\section{Solo service-user voice}

People on the receiving end of welfare and social services, often not by choice, or often because they are actively seeking out help, have a right to speak. Solo service-user voice allows them to provide narratives or accounts of the services they receive, or the ways in which they negotiate relationship with various professionals (social workers, educational professionals, psychologists, teachers), or voice about aspects of their lived experiences. In the past, service users with disabilities and mental health issues have been the most vocal in telling of their experiences, but more recently service users from criminal justice, child and family social work, palliative care and older person's care have been forthcoming (Beresford, Adshead and Croft 2007; Cree and Davis 2006).

Teachman and Gibson (2012) call these experiences first hand. For service-users to be able to tell their stories, themselves, perhaps with support of a practitioner, it is an important way of understanding their lived world; as Lewis (2011: 505) points out, 'it is enough just to tell the story'. However, it is also important to get enough material to be able to reflect, analyse and write the story. This goes for the service-user who might want to talk about their experience of an intervention, or for others writing up the service-user's story. Teachman and Gibson (2012) in their article about children with disabilities described how to maximise the single qualitative interview, in other words just one story at one time. If we imagine four or five members of one family with many information sources we could amass a great deal of material around a single case. The sources and information gathering techniques mentioned by Teachman and Gibson included: sentence starters; warm-up activities - talking cards, cartoon captioning - filling in speech bubbles; presenting photographs (all designed to get children relaxed, feeling safe, having fun and talking); use of vignettes to present hypothetical situations; role play using puppets; interviews and conversations with children; interviews and conversations with parents. In the Teachman and Gibson study an interview with a child was maximised for data gathering, and was tailor made to include relevant vignettes, photos, cartoons and sentence starters. It was done to also ensure the child felt comfortable and could fully participate - interviews were non-intrusive, which is the hallmark of a One Voice strategy.

Empowerment and social justice have always been fundamental aims of social work (ISFW, 2012) and solo service-user voice allows practitioners to encourage individual service-users or families to make their story known to achieve these aims. How realistic is this? With most vulnerable families it is not easy, but practitioners may feel comfortable with working collaboratively with a one or two service-users, and either writing collaboratively or allowing the service-user to tell their story to them and then writing it up for them. The service-user must feel it would be of use either to them or in helping others. A good example of a service-user story, written by others, and illustrating social work themes like 
empowerment, hope, emotion and equality is developed in Davis (2006). Beresford and Carr (2012) have also long advocated for considerable service-user voice and involvement in all aspects of research and practice, and while it may be a strategy for only a few, social work practitioners could encourage more service users to speak about their experiences.

\section{Reflective case study analysis}

This strategy has a reflective and auto-ethnographic focus but is applied to a single case more often a single family, but could still be an individual or an organisation. The case study is the unit of analysis and will be studied in-depth, to understand its uniqueness and particularity, and what new insights it might offer on little-known or well-known topics (Stake 1995). The case study can be both instrumental, illustrating themes around a phenomena, or intrinsic - allowing the author to discuss the details of the case itself (Court and Abbas 2013; Stake 1995). The reflective elements occur from informal data gathering, experiential data gathering - ad hoc observations, informal conversations, diary-keeping and making sense of these. Busy social work practitioners can easily do this for a case. It is about exploring the case and the impact of particular events upon that case. If done well, a case study will capture the complexity of a particular family and their needs.

A good example presented as a TV documentary in 2012 was a programme called 'Protecting Our Children' (BBC 2012) which followed families and their child protection social workers for 12 months. One programme was focused on a couple and their three-year-old son, and the professionals who were intervening in their lives. Every angle was covered about their particular parenting dilemmas and the documentary illustrated key themes around good parenting, bad parenting, the State's role in protection, the impact of the State through social worker or court actions, and discourse of the family. This documentary could easily have been a piece of family-based practice and written up as a unique case study, with significant input from the family involved. From its publication we would have learned much about the lived experiences of vulnerable families struggling with poverty, low educational achievement, drug and alcohol issues and so on.

Some key issues in using case studies are explored by Flyvbjerg (2006). He notes that case studies are often criticised as not being able to offer insights or new theory beyond the actual case. He argues the case studies can contribute to theory and concept development as they are explored in great detail, and that case studies are ideal ways to present knowledge of human affairs because case studies are uniquely context-dependent and illustrate many meanings and themes around a given problem (Hammond and Cooper 2010; Mason 2013; Solem 2011). As with all One Voice strategies, case studies provide real life accounts.

\section{The strengths and weaknesses of One Voice strategies}

Swenson tells us that 'narrative structures are the bedrock of human experience' (2012: 234). The strengths of One Voice strategies are many and varied, not least because any narrative is valid, and can help tell a story, to be used for advocacy and justice (Davis 2006). One Voice strategies are first order, authentic and eye witness in nature - 'I was there, I saw what happened'. A One Voice strategy allows people the authority to speak with their own voice (Swenson 2012). While many qualitative strategies do give some voice to the service-user or practitioner, One Voice strategies in particular send a clear message that a specific service-user or practitioner has material of importance to be shared and 
understood. One Voice strategies can be a trigger for more research, and asking the bigger questions. The search for knowledge can occur in many ways and One Voice strategies allow knowledge to be created with the emphasis on individual worth and respect, core values of social work generally (Swenson 2012). One Voice strategies might illustrate some major themes around a seemingly small, unique issue but then pave the way to help others experiencing similar stories, either to offer hope or enable them to tell their story. For example, I was contacted by someone in a similar situation who told me my story brought comfort and that I could tell her story too to add weight to my next piece on the same issue. My local MP used my story to make further enquires on the topic I presented to him (Gibbs 2011).

Inevitably, there are limitations of One Voice strategies. For example, using only one account might make it difficult to make a case for change. You might not get taken seriously - people may say your case is a, 'once in a blue moon' occurrence - your situation is 'too unique'. Flyvbjerg (2006) suggests that case studies can be done well or poorly and when the study has poor rigour with only limited analysis then in all likelihood the story might not be taken seriously. The important task therefore in using One Voice strategies is to ensure that extensive diary or field notes are taken; there is a clear aim of exploring the case; and that analysis occurs alongside a robust reviewing of key literature and research in the topic area. I recently completed a journal article using auto-ethnography and a non de plume with around 50 references in the topic area, and because the article was based on only one family story it was necessary to present a large amount of relevant literature and research on the topic.

Another area where there might be a limitation is in the area of harm, for example, the identification and exposure of yourself or your family or employer might result in unwarranted attention and criticism. It is always important to reflect on the likely impact of exposure for people who are the subject of the personalised account, sometimes the non de plume is the only way forward, but other times it is a case of choosing to leave the more harmful material out (Chatham-Carpenter 2010). One adoption-focused journal turned down the piece I mention below because of identification issues, but in doing so denied my family its voice - the piece was eventually permitted by a different child welfare journal (Gibbs 2011).

Finally, getting enough material to be able write a story in a detailed way and to use the story meaningfully to illustrate themes as well as aid lessons to be learnt can be a challenge. Painstaking note-keeping may assist, and conversations and interviews with the main people in the narrative involves these people in contributing to the story, and ensures that reflective analysis occurs which links the personal to the social, cultural, political, economic and other contexts of relevance to the main topic under discussion (Ellis, Adams and Bochner 2011; Jensen-Hart and Williams 2010). Using a One Voice strategy allows practitioners, service-users, families and researchers the opportunity to bring their story to others, but with a reflective and critical analysis connected to a range of contexts, other people's similar experiences and previous research.

\section{Are One Voice strategies research?}

Although not crucial, it is worth asking the question are these One Voice strategies research? If one views research as being about real life then these strategies are real life, and therefore 
should be considered research. But if you need numbers to make the story(s) count, or, if you are trying to persuade someone to part with some money, or perhaps make a policy change then maybe you would not use One Voice strategies to make your point. Donmoyer argues differently: 'Policymakers may value statistical data and analysis in their public discourse, in private, however if you want to convince them of something, tell them a good story.' (Donmoyer 2012: 805). If different methods produce different stories, presented in different ways, then One Voice strategies are methods that contribute to research and can still make a difference (Jensen-Hart and Williams 2010).

A One Voice strategy is worthy of reporting in academic journals and not just blogs, magazines or newspaper accounts. Although it can be subjective, opinionated and political in nature, leaving the personal agenda aspect of it open to criticism that it is not research, much feminist and constructivist research has the same features, and has suffered the same criticisms, and yet has become accepted as research (Cooper 2001; Anderson-Nathe, Gringeri and Wahab 2013). There are many ways to define research - and if you believe anything is researchable or that research is about answering questions, then One Voice strategies are valid research strategies (Gibbs 2013a). Jensen-Hart and Williams (2010) make a strong argument in favour of auto-ethnography being an acceptable research strategy for social workers - they argue that this strategy allows for critical reflection and reflexivity that are essential habits in social work practice. Furthermore, the assumptions behind an artistic understanding of auto-ethnography reflect social constructionist and postmodern theories and not those of positivism (Jensen-Hart and Williams 2010). Hence, an objective and scientific definition of research is unlikely to allow One Voice strategies to be accepted as research but a more nuanced and subjective assessment incorporates such strategies as acceptable research practices.

Ellis, Adams and Bochner (2011) and Wall (2008; 2012) have argued convincingly that we can view auto-ethnography as credible and trustworthy, but that inevitably it will always be subject to criticisms from those who do not view it as research, especially from those who view research only as a scientific undertaking. The same can be said for all One Voice strategies. They produce compelling material which resonates with the audiences that read or listen to the accounts, but One Voice strategies are still likely to be viewed as less important than those produced by scientific processes designed to develop new knowledge. One Voice strategies nevertheless do produce 'new' knowledge and new reflections, and can often be a catalyst for socially just responses to issues impacting the lives of just a few people.

If practitioners are to use these strategies then they need to be clear about the focus of their reports, and be prepared to gather 'data' in the sense of notes, material from informal and formal conversations and they will need to reflect critically on the material, perhaps using some analytic frameworks from qualitative research guides (e.g. Denzin and Lincoln 1998; McLaughlin 2012; Smith 2009). They will need to present their material in a logical format and enhance their accounts with appropriate literature and research material from the field of family-centred social work. There are many excellent 'how-to guides' to doing reflective research of the kind intimated through One Voice strategies and practitioners might find reading the following texts useful: 'Doing Social Work Research' (Smith 2009); 'Social Care, Service Users and User Involvement' (Beresford and Carr 2012); 'Autoethnography: An Overview' (Ellis, Adams and Bochner 2011); and 'The Art of Case Study Research' (Stake 1995). 


\section{Application and examples to family-centred social work practice}

In this section I will draw on examples of where I have been able to publish from my own everyday reality of being a practitioner, a service-user and a researcher. My role is perhaps more unique than some in that I can fit into many categories but perhaps not - think about this - you are a practitioner, you might be a service-user in some capacity and maybe you are more of a low-key researcher of your everyday occupation than you think. So, how have I used these One Voice strategies?

\section{The policy and practice of double-adoption}

This was the first piece I wrote of a more auto-ethnographic nature exploring a particular policy around adopting children twice when moving from one place to another (Gibbs 2011). It was an issue of justice and children's rights, and explored the experiences of my own family during a period of nine months in 2010 when we returned to the UK from New Zealand with children we had adopted from Russia. To enable this piece to get published in a reputable child welfare journal I reflected upon a range of formal and informal data sources: I used diary keeping and note-taking; reviewed relevant documents; had informal conversations with family members; and engaged in both informal and formal conversations with adoption professionals, other professionals and other adoptive parents. Apart from telling the story I presented concrete policy recommendations, in order to prevent future loss of children's right. This piece was both reflective case study and auto-ethnography.

\section{Adoptive parents as experts}

This is an ongoing project exploring ideas about expert and professionalised discourses and practices of parenting adopted children. It draws on the literature, as well as material from a range of experiential sources, both formal and informal. These might be meetings with other parents to consider how we actively parent our adopted and biological children; observational reflections on meeting with specialised adoption social workers and psychologists; and attendance at therapy groups. The material gathered from informal and formal sources will add to my own service-user perspective on the helpfulness of adoption professionals on parenting, and my own auto-ethnography of how I attempt to be an expert parent to my own adopted children. The piece I would like to write will explore what it means to become and stay an Expert Adoptive Parent, and how this makes an impact on real parenting in the everyday lived reality; negotiating relationships with professionals; and our knowledge of the challenges and delights of being an adoptive parent, with implications for policy and practice.

\section{The needs of adopted and fostered children in New Zealand}

In a recent book chapter for a New Zealand published book on childhoods (Gibbs 2013b), I have drawn on personal lived experience to construct a vignette at the outset of the chapter, and then worked the discussion of the needs of adopted and fostered children in New Zealand around this vignette. I have also drawn on my interactions with welfare, education and health agencies, and with other adoptive and foster families over the years in both the UK and New Zealand, to explore the challenges faced by adoptive and foster families and how to best support such families as they attempt to maximise their children's wellbeing.

Further examples that family-centred practitioners could use themselves might be writing about the organisation they work for, in a similar vein to $A$ day in the life of a hospital social worker, written by Craig (2007). How about A day in the life of a family social worker or, 
Institutional barriers and strengths to good practice in work with families? The list is potentially endless. Perhaps a team of social work practitioners could get together to write a piece about the models they are using in work with families; this would share the burden of writing and be extremely creative! If one were to write auto-ethnography, especially if it was potentially controversial, then perhaps the practitioner could use a non de plume and ensure that identifying features of an agency were removed - this way a practitioner may be able to be appropriately critical of how agencies work well or poorly with families, but still with the overall aim of improving family-centred practice and telling a story that ought to be told. In case study accounts too, practitioners could explore the case in-depth and outline aspects of practice that worked well and aspects that did not work so well, all of which could be used to suggest policy and practice change to promote best practice. Finally, practitioners might want to encourage a particular family to tell their service-user story so that their experiences of care and protection are heard. We can learn so much from service-users and they should not be excluded from solutions to the problems they face.

\section{Conclusion}

One Voice strategies have something unique to offer. Potentially, they make the most of what is already going on in practice and presenting it carefully with a critical analysis. The accounts produced are authentic and first hand. They can add to or create new policy. They can explore complexity, events, topics and relationships in-depth. They have a social justice angle. The downside is that using One Voice strategies may miss the bigger picture. But if more social work practitioners tell us about their One Voice experiences, or service-users tell us their stories, then such precious material will allow for the development of a bigger picture of lived experiences for families and individuals in social work contexts. If practitioners all add something to the bigger picture then we gain both a robust and collective understanding of everyday practice and reality.

\section{References}

Anderson-Nathe, B., Gringeri, C., \& Wahab, S. (2013). Nurturing 'critical hope' in teaching feminist social work research. Journal of Social Work Education 49(2): 277-291.

Atkinson, P. (2013). Blowing hot: The ethnography of craft and the craft of ethnography. Qualitative Inquiry 19(5): 397-404.

BBC (2012). Protecting our children. Accessed 24th April 2013, from http:/ / www.bbc.co.uk/mediacentre/proginfo/2012/05/ protecting-our-children.html.

Beresford, P., \& Carr, S. (2012). Social care, service users and user involvement. London: Jessica Kingsley.

Beresford, P., Adshead, L., \& Croft, S. (2007). Palliative care, social work and service users: Making life possible. Jessica Kingsley: London.

Chatham-Carpenter, A. (2010). 'Do thyself no harm': Protecting ourselves as autoethnographers, Journal of Research Practice 6(1): Art. M1, accessed 23rd September 2013, from http:/ /jrp.icaap.org/index.php/jrp/article / view / 213/183.

Cooper, B. (2001). Constructivism in social work: Towards a participative practice viability. British Journal of Social Work 31(5): 721-738.

Craig, R.W. (2007). A day in the life of a hospital social worker - Presenting our role through the personal narrative. Qualitative Social Work 6(4): 431-446.

Cree, V., \& Davis, A. (2006). Social work; Voices from the inside. Abingdon: Routledge.

Court, D., \& Abbas, R. (2013). Whose interview is it, anyway? Methodological and ethical challenges of insider-outsider research, multiple languages, and dual-researcher cooperation. Qualitative Inquiry 19(6): 480-488.

Davis, C. (2006). Sylvia's story - Narrative, storytelling, and power in a children's community mental health system of care. Qualitative Inquiry 12(6): 1220-1243.

Denzin, N. (2006). Analytic autoethnography, or déjà vu all over again. Journal of Contemporary Ethnography 35(4): 419-428.

Denzin, N., \& Lincoln, Y. (Eds.) (1998). Collecting and interpreting qualitative materials. Thousand Oaks: SAGE. 
Donmoyer, R. (2012). Two (very) different worlds: The cultures of policymaking and qualitative research. Qualitative Inquiry 18(9): 798-807.

Dumbleton, S. (2013). Goodies and baddies: Equivocal thoughts about families using an autoethnographic approach to explore some tensions between service providers and families of people with learning disabilities. 7(3): 282-292.

Ellis, C. (2013). Crossing the rabbit hole: Autoethnographic life review. Qualitative Inquiry 19(1): 35-45.

Ellis, C., Adams, T., \& Bochner, A. (2011). Autoethnography: An overview. Qualitative Social Research 12(1): art.10, http: / / nbn-resolving.de/urn:nbn:de:0114-fqs1101108.

Ellis, C., \& Bochner, A. (2006). Analysing analytic autoethnography: An autopsy. Journal of Contemporary Ethnography 35(4): 429-449.

Flyvbjerg, B. (2006). Five misunderstandings about case study research. Qualitative Inquiry 12(2): 219-249.

Gibbs, A. (2011). Having to adopt children twice is not in the children's best interests: A reflective case study analysis of intercountry adoption policy in the UK. Journal of Social Welfare and Family Law 33(3): 267-277.

Gibbs, A. (2012). What do social work students think social work research is? Aotearoa New Zealand Social Work 24(2): 19-26.

Gibbs, A. (2013a). What would a scholarship of publication look like? Higher Education Research and Development 32(4): 687-689.

Gibbs, A. (2013b). The needs of adopted and fostered children. In N. Higgins \& C. Freeman (Eds.), Childhoods: Growing up in Aotearoa/New Zealand. Dunedin: Otago University Press.

Hammond, S., \& Cooper, N. (2010). From looked after children to looking after children: Insight from an unusual perspective. International Social Work 54(2): 238-245.

Jensen-Hart, S., \& Williams, D. (2010). Blending voices: Autoethnography as a vehicle for critical reflection in social work. 30(4): 450-467.

IFSW (2012). Definition of social work. Accessed 24th April, 2013, from http:/ / ifsw.org/policies/definition-of-social-work/.

Lewis, P. (2011). Research as storytelling. Qualitative Inquiry 17(6): 505-510.

Mason, L. (2013). The journey of one pregnant incarcerated woman through systemic bias: How family support workers can positively affect change - A case study. Affilia 28(1): 32-39.

McKenzie, M. (2008). You should write that up: Getting practitioners started on writing for publication. Aotearoa New Zealand Social Work 20(2): 86-91.

McLaughlin, H. (2012). Understanding Social Work Research. London: SAGE.

Morse, J. (2002). Writing my own experience. Qualitative Health Research 12(9): 1159-1160.

Munford, R. \& Sanders, J. (2003). (Eds.) Making a difference in families: Research that creates change. St Leonards: Allen and Unwin.

Orme, J., \& Powell, J. (2007). Building research capacity in social work: Process and issues. British Journal of Social Work 38(5): 988-1008.

Osmond, J., \& O'Connor, I. (2006). Use of theory and research in social work practice: Implications for knowledge-based practice. Australian Social Work 59(1): 5-19.

Solem, M.B. (2011). Meaning making and avoidance in parenting. Qualitative Social Work 12(2): 170-185.

Smith, R. (2009). Doing social work research. Maidenhead: Open University Press.

Speedy, J. (2013). Where the wild dreams are. Qualitative Inquiry 19(1): 27-34.

Stake, R. (1995). The art of case study research. Thousand Oaks, CA: Sage.

Swain, A. (2013). Waiting for daybreak: A survivor's account of theft and recovery. Qualitative Inquiry 19(7): $502-504$.

Swenson, C. (2012). Dare to say 'I'; The personal voice in professional writing. Families in Society 93(3): 233-239.

Teachman, G., \& Gibson, B. (2012). Children and youth with disabilities: Innovative methods for single qualitative interviews. Qualitative Health Research XX(X): 1-11.

Tolich, M. (2010). A critique of current practice: Ten foundational guidelines for autoethnographers. Qualitative Health Research 20(12): 1599-1610.

Wall, S. (2008). Easier said than done: Writing and autoethnography, International Journal of Qualitative Methods 7(1): 38-53.

Wall. S. (2012). Ethics and the socio-political context of international adoption: Speaking from the eye of the storm. Ethics and Social Welfare 6(4): 318-332. 